\title{
Cytological Effect of the Plant Hormone Putrescine on Allium cepa Root Tips
}

\author{
Atef S. Haliem $^{1 *}$, Hoda M. Barakat ${ }^{1}$, Hala M. Mahfouz ${ }^{1}$, Mahmoud M. El-Tohamy ${ }^{2}$ \\ ${ }^{1}$ Department of Botany, Faculty of Science, Ain Shams University, Abbassia, 11566, Cairo. Egypt. \\ ${ }^{2}$ Academy of scientific research and technology grant student
}

A R T I C LE IN F O

Article history:

Received 21 October 2010

Accepted 23 October 2010

Keywords:

Polyamines;

Putrescine;

Allium cepa;

Mitotic index:

Cell cycle.

\begin{abstract}
A B S T R A C T
Much attention was paid for putrescine as important plant hormone involved in stress signalling and response in plant. In this study root tips of Allium cepa were treated with different putrescine concentrations ranging from 6.25 to $0.78 \mathrm{mM}$ for 3,6 and 24 hours. The effect of putrescine on mitotic activity, induction of mitotic abnormalities, DNA index and changes in the different parameters of the cell cycle has been investigated.

At the cytological level putrescine caused reduction in mitotic index and induced a number of chromosomal abnormalities. The cell cycle analysis showed drastic alternation in different cell cycle phase percentages and the DNA indices as compared with control. Finally, putrescine has mutagenic potentialities expressed in its ability for induction of mitotic abnormalities and alternation of cell cycle phases.
\end{abstract}

\section{Introduction}

Plant hormones and other growth regulators play a vital role in different aspects of plant growth and development. Now, it is still clear that the path of development is under the hormonal control, via changes in hormone levels in response to change in gene transcription or with the hormones themselves as regulators of gene expression ${ }^{1}$.

The commonly recognized classes of plant hormones are auxins, gibberellins, cytokinins, abscisic acid and ethylene. Recently putrescine gained much interest in controlling a variety of plant processes.

Polyamines such as putrescine, spermine and spermidine are present in all living organisms. They are important for cell division as there is a positive correlation between the proliferative activity of cells and their content ${ }^{2-5}$.

The wide use of theses hormones imposes the importance to screen their mutagenic potentialities before their application to environment to avoid their negative impact on the quality of human life.

The present study aims to investigate the effect of putrescine on mitotic cell division in Allium cepa root tips and its ability to induce chromosomal aberrations.

This work also focus on the use of image cytometry for the estimation of changes in cell cycle progression.

\footnotetext{
* Corresponding author.

E-mail address: atef.saad@live.com
}

\section{Materials \& Methods}

Plant materials

Allium cepa (variety Giza 6) was used as experimental plant for chromosome aberration assay and cell cycle analysis.

Test chemical

\begin{tabular}{|l|l|l|}
\hline \multicolumn{4}{|c|}{ 1. Putrescine } \\
\hline Formula & $\mathrm{C}_{4} \mathrm{H}_{12} \mathrm{~N}_{2}$ & $\mathrm{H}_{2} \mathrm{~N}$ \\
\hline Mol wt. & $88.1516[\mathrm{~g} / \mathrm{mol}]$ & \\
${ }^{2}$
\end{tabular}

\section{Used concentrations}

A series of gradual concentrations: $6.25,3.12,1.56$ and $0.78 \mathrm{mM}$ were used for different periods of time ranging from 3 to 24 hours. All treatments were carried out in the incubator at $20-25^{\circ} \mathrm{C}$ and continuous renewal of treatment solution was done.

\section{Cytological procedures}

\section{A. Squash technique}

Bulbs of Allium cepa were allowed to germinate in tap water. When the roots reached $2-3 \mathrm{~cm}$ long, they were transferred to the test solutions for the treatment time. The treated roots were fixed in carnoy's solution [absolute alcohol: glacial acetic acid (3:1)] for 24 hours, then hydrolyzed in $1 \mathrm{~N}$ analar $\mathrm{HCL}$ at $58^{\circ} \mathrm{C}$ for about $6-$ 8 minutes, followed by staining with Leuobasic Fuchsin 
according to Darlington and La Cour ${ }^{\circ}$. Light green dye $(0.3 \%)$ was used for staining the protoplasm.

The root tips were squashed in $45 \%$ acetic acid and mounted in Canada balsam with a clean slide and placed in an oven at $35-45^{\circ} \mathrm{C}$ for $2-3$ days to dry. The preparations were examined microscopically, 90 fields were completely analyzed for each concentration. The photomicrographs were taken from the prepared slides.

\section{Statistical analyses:}

The frequencies of different stages of mitosis as well as the frequencies of different mitotic abnormalities were determined. Mitotic indices and total abnormalities were statistically analyzed using (t-test).

\section{B. Cytophotometric measurements of DNA ploidy in cells}

The nuclear DNA was stained with Feulgen stain ${ }^{6}$. The content of the stained DNA can be estimated using Leica Qwin 500 image analyzer system ${ }^{7}$. After DNA staining, the nuclear-integrated optical density is the cytometric equivalent of its DNA content.

The content of DNA in the nucleus, DNA index and the frequencies of different phases of cell cycle were calculated. These include cells with DNA amount less than the $2 \mathrm{C}$ value, cells with $2 \mathrm{C}$ DNA $\left(\mathrm{G}_{0} / \mathrm{G}_{1}\right)$, cells with 3C- 4C DNA (S-phase), cells with 4C DNA $\left(\mathrm{G}_{2}\right.$ phase) and cells with DNA more than $4 \mathrm{C}$ value ${ }^{8-10^{2}}$. Statistical analysis was already given with analysis program.

\section{Results and Discussion}

One of the major effects of putrescine in this work is its influence on the rate of mitotic division. In general, after all treatments with putrescine (3, 6 and 24 hours) it was clear that, the mitotic index (MI) values decreased gradually with the increase of putrescine concentration as compared with the control (Table1). However, the lowest concentration $(0.78 \mathrm{mM})$ and the moderate one $(1.56 \mathrm{mM})$ showed a gradual increase in MI values with the increase of the period of treatment. Such behavior was not clear after treatment with the highest concentration $(6.25 \mathrm{mM})$.

The reduction in MI especially after treatments with high concentrations reflects the cytotoxic potential of putrescine. Such reduction in MI may be due to blocking of cell cycle during interphase ${ }^{11}$, inhibition of nuclear protein synthesis essential in the cell cycle ${ }^{12}$, blocking $\mathrm{G}_{1}$ phase and preventing DNA synthesis ${ }^{13}$, suppressing DNA synthesis ${ }^{14}$ and interference with cell cycle by preventing the progression of cells from $\mathrm{G}_{2}$ phase to mitosis ${ }^{15-16}$.

Treatments with putrescine induced a significant percentage of abnormal mitosis. This percentage increased as the concentration of putrescine and the time of treatment increased (Table 1).

The most frequent types of abnormalities were stickiness, disturbed phases, bridges, laggards, fragments and multipolar cells. Chromosome stickiness was common especially after treatment with high conc- entration, Chromosome stickiness reflects highly toxic effects, usually of an irreversible type probably leading to cell death ${ }^{17}$. Stickiness may be due to disturbances in cytochemically balanced reactions of nucleosomes formation ${ }^{18}$ andlor for defective functioning of one or two types of specific non-histone proteins involved in chromosome organization that are needed for chromatid separation and segregation ${ }^{19}$.

Another common type of aberrations recorded at anatelophase stages after putrescine treatments was chromosome and lor chromatin bridges. Their frequencies increased gradually with the increase of putrescine concentration. These bridges may be due to breakage and reunion with the formation of dicentric chromosome and acentric fragments or due to chromosome stickiness and subsequent failure of anaphase separation ${ }^{20}$ andlor due to unequal translocation or inversion of chromosome segments ${ }^{21-22}$. Most concentrations of putrescine caused complete inhibition of spindle fibres leading to the formation of $\mathrm{C}$-metaphase either $2 \mathrm{~N}$ or $4 \mathrm{~N}$. C-mitosis may be due to the poisons action of putrescine on the microtubules leading to block in mitosis at metaphase and depolymerization of spindle microtubules, thus producing colchicine-like effects. If the effect on spindle is partial it leads to aberration as disturbances and laggard abnormalities. These results are concomitant with those obtained by some investigators using different mutagenic agents ${ }^{23-26}$.

High concentrations of putrescine induced the formation of apoptosis which is one of different types of cell death including necrosis, cytostasis and DNA damage detected recently by cytokinesis block micronucleus assay ${ }^{27-28}$. Apoptosis is characterized by cytoplasmic shrinkage, membrane blebbing, loss of cell to-cell contact, fragmentation of DNA at inter-nucleomosomal $\operatorname{sites}^{29-30}$. Apoptosis involved in the selective elimination of cells ${ }^{31}$.

The effect of putrescine on cell cycle phases is represented in Table (2). The frequency of cells with $2 \mathrm{C}$ value $\left(G_{1}\right.$ phase $)$ is sharply declined with the increase of putrescine concentration as compared with control. It reached zero value after treatment with the high concentration $(6.25 \mathrm{mM})$ for 24 hours. On the other hand, the frequencies of $S$ and $\mathrm{G}_{2}$ phases after treatment with all concentrations of putrescine were higher than the control.

The most evident effect of putrescine appears to be the accumulation of cells in the $S$ and $G_{2}$ phases associated with reduction in the proportion of cells in $G_{0} \backslash G_{1}$ these results indicate that putrescine hormone acts as inhibitor to cell cycle at the G2 transition point at high concentration. Cell cycle progression is controlled by check points that mediate the entry into S-phase and mitosis the progression through theses check points is catalyzed by a group of cyclin dependant kinases with activity depends on the association with different classes of cyclins ${ }^{32}$. 
Table 1: Frequency of different types of prophase, metaphase and ana-telophase abnormalities, mitotic index and mean percentage of abnormal mitosis after treating Allium cepa root tips with different concentrations of putrescine for 3,6 and 24 hours.

\begin{tabular}{|c|c|c|c|c|c|c|c|c|c|c|c|c|c|c|c|c|c|c|}
\hline \multirow{2}{*}{$\begin{array}{c}\text { Treatment } \\
\text { mM }\end{array}$} & \multicolumn{3}{|c|}{$\begin{array}{l}\% \text { of Prophase } \\
\text { abnormalities }\end{array}$} & \multicolumn{7}{|c|}{$\%$ of metaphase abnormalities } & \multicolumn{6}{|c|}{$\begin{array}{c}\% \text { of anaphase-telophase } \\
\text { abnormalities }\end{array}$} & \multirow{2}{*}{$\begin{array}{c}\text { Mean MI } \\
\% \\
\text { SE } \pm\end{array}$} & \multirow{2}{*}{$\begin{array}{c}\text { Mean\% of } \\
\text { abnormal } \\
\text { mitosis } \\
\mathrm{SE} \pm\end{array}$} \\
\hline & Stick & Split & Irrg. & $\mathrm{CM}(2 \mathrm{~N})$ & $\operatorname{CM}(4 \mathbf{N})$ & Star & Break & Stick & Dist. & Lag. & Lag. & Brid. & Multi. & Break & Stick & Dist. & & \\
\hline \multicolumn{19}{|c|}{3 hours } \\
\hline Control & & & & & & & & & 2.15 & 2.15 & & & & & & 3.88 & $4.20 \pm 0.08$ & $2.69 \pm 0.90$ \\
\hline 0.78 & 4.76 & & 3.57 & & 1.12 & & 1.12 & 7.87 & 8.99 & 3.37 & 1.02 & 8.16 & 1.02 & & 5.11 & 4.08 & $3.37 \pm 0.15$ & $16.97 \pm 1.41$ \\
\hline 1.56 & 13.04 & 10.15 & 15.94 & 8.00 & & 2.00 & & 2.00 & 30.00 & 8.00 & 4.29 & 14.29 & & 4.29 & 12.85 & 8.57 & $2.49 \pm 0.01$ & $43.92 \pm 0.26$ \\
\hline 3.12 & 15.69 & 3.92 & 27.45 & 1.85 & 3.70 & 1.86 & 3.70 & 27.78 & 24.07 & 5.56 & 5.95 & 13.11 & 3.57 & 4.76 & 28.57 & 9.52 & $2.35 \pm 0.05$ & $61.38 \pm 0.26^{* *}$ \\
\hline 6.25 & 19.38 & 16.00 & 27.12 & & & 7.41 & & 70.37 & 11.11 & 0.00 & & 26.37 & 2.50 & 7.50 & 16.25 & 12.5 & $1.92 \pm 0.09 *$ & $68.32 \pm 1.99 * *$ \\
\hline \multicolumn{19}{|c|}{6 hours } \\
\hline Control & & 0.82 & 0.82 & 0.99 & & & & & 2.97 & & 1.19 & & & & & 2.38 & $4.64 \pm 0.07$ & $3.08 \pm 0.81$ \\
\hline 0.78125 & 1.89 & 0.94 & 5.50 & 2.33 & & & 2.33 & 1.16 & 15.12 & 3.48 & 0.83 & 3.30 & 1.65 & 0.83 & 0.83 & 4.13 & $3.95 \pm 0.10$ & $13.97 \pm 0.39$ \\
\hline 1.5625 & 4.48 & 2.99 & 17.90 & 5.56 & 1.39 & 1.39 & 1.39 & 6.94 & 25.00 & 6.94 & 1.35 & 9.46 & & 1.35 & 8.12 & 14.86 & $2.60 \pm 0.05$ & $36.62 \pm 2.02 *$ \\
\hline 3.125 & 21.31 & 9.84 & 34.42 & 3.85 & 1.92 & & 7.69 & 42.31 & 15.38 & 3.85 & 8.43 & 21.66 & & 5.00 & 23.33 & 10.00 & $2.15 \pm 0.03 *$ & $\begin{array}{l}69.36 \pm \\
1.08 * *\end{array}$ \\
\hline 6.25 & 10.53 & 12.50 & 39.47 & 1.59 & & 3.17 & 6.35 & 46.03 & 11.11 & 6.35 & 4.17 & 30.56 & 8.33 & 5.56 & 19.44 & 11.11 & $2.04 \pm 0.03 * *$ & $\begin{array}{l}74.25 \pm \\
1.01 * *\end{array}$ \\
\hline \multicolumn{19}{|c|}{24 hours } \\
\hline Control & & 1.56 & & & & & & & 1.00 & & & 1.32 & & & & & $4.46 \pm 0.03$ & $1.32 \pm 0.54$ \\
\hline 0.78 & 3.33 & 6.67 & 12.22 & 5.95 & 2.38 & 1.19 & 2.38 & 9.53 & 15.48 & 3.57 & 0.86 & 4.31 & 0.86 & 0.86 & 6.91 & 7.75 & $3.99 \pm 0.05$ & $27.24 \pm 0.25$ \\
\hline 1.56 & 5.88 & 2.35 & 14.12 & 5.80 & 1.45 & & 2.90 & 8.70 & 20.28 & 4.35 & 7.07 & 11.11 & & 3.03 & 11.11 & 15.15 & $3.00 \pm 0.05^{*}$ & $37.94 \pm 1.77^{*}$ \\
\hline 3.12 & 20.00 & 4.62 & 36.92 & 1.43 & 1.43 & 4.29 & 2.86 & 37.14 & 21.43 & 12.85 & 6.85 & 24.66 & 1.75 & 1.75 & 23.29 & 12.38 & $2.54 \pm 0.05^{*}$ & $\begin{array}{l}71.43 \pm \\
0.18 * *\end{array}$ \\
\hline 6.25 & 16.46 & 5.71 & 65.71 & 4.35 & & 1.45 & & 36.23 & 27.54 & 10.14 & 5.08 & 35.59 & & 1.69 & 30.53 & 8.47 & $2.00 \pm 0.07 * *$ & $\begin{array}{l}81.99 \pm \\
0.66 * *\end{array}$ \\
\hline
\end{tabular}

Table 2: Effect of putrescine on the cell cycle parameters in root meristematic cells of Allium cepa treated for 3 and 24 hours.

\begin{tabular}{|c|c|c|c|c|c|c|}
\hline \multicolumn{7}{|c|}{3 hours } \\
\hline Conc. $\mathbf{m M}$ & DNA $<2 \mathrm{c} \pm$ SD & G1 phase \pm SD & S-phase \pm SD & G2 phase \pm SD & DNA $>4 C \pm \mathrm{SD}$ & $\begin{array}{c}\text { DNA index } \\
\pm \text { SD }\end{array}$ \\
\hline 6.25 & $\mathbf{0}$ & $2.6 \pm 0.281$ & $29.9 \pm 0.263$ & $28.2 \pm 0.294$ & $39.3 \pm 0.779$ & $1.93 \pm 1.18$ \\
\hline 3.125 & $\mathbf{0}$ & $3.0 \pm 0.082$ & $27.0 \pm 0.3$ & $33.0 \pm 0.317$ & $37.0 \pm 0.865$ & $1.93 \pm 1.14$ \\
\hline 1.5625 & $\mathbf{0}$ & $9.3 \pm 0.187$ & $33.3 \pm 0.281$ & $25.0 \pm 0.237$ & $32.4 \pm 1.45$ & $1.92 \pm 1.70$ \\
\hline 0.78125 & $1.9 \pm 0.042$ & $19.2 \pm 0.266$ & $45.2 \pm 0.302$ & $15.4 \pm 0.303$ & $18.3 \pm 1.03$ & $1.6 \pm 1.28$ \\
\hline control & $16.7 \pm 0.19$ & $47.6 \pm 0.281$ & $23.8 \pm 0.354$ & $11.9 \pm 0.344$ & 0.0 & $1 \pm 0.70$ \\
\hline \multicolumn{7}{|c|}{24 hours } \\
\hline 6.25 & $\mathbf{0}$ & $\mathbf{0}$ & $15.25 \pm 0.22$ & $26.27 \pm 0.27$ & $58.48 \pm 0.73$ & $2.18 \pm 1.10$ \\
\hline 3.125 & $1.79 \pm 0.01$ & $10.29 \pm 0.28$ & $25.0 \pm 0.31$ & $14.1 \pm 0.37$ & $48.21 \pm 0.64$ & $2.12 \pm 0.79$ \\
\hline 1.5625 & $1.60 \pm 1.03$ & $18.40 \pm 0.20$ & $36.0 \pm 0.28$ & $29.60 \pm 0.27$ & $14.40 \pm 1.05$ & $1.6 \pm 1.18$ \\
\hline 0.78125 & $\mathbf{0}$ & $44.62 \pm 0.25$ & $30.0 \pm 0.26$ & $16.15 \pm 0.27$ & $9.23 \pm 0.77$ & $1.36 \pm 1.20$ \\
\hline control & $16.67 \pm 0.19$ & $47.62 \pm 0.28$ & $23.81 \pm 0.35$ & $11.91 \pm 0.34$ & $\mathbf{0}$ & $1 \pm 0.70$ \\
\hline
\end{tabular}




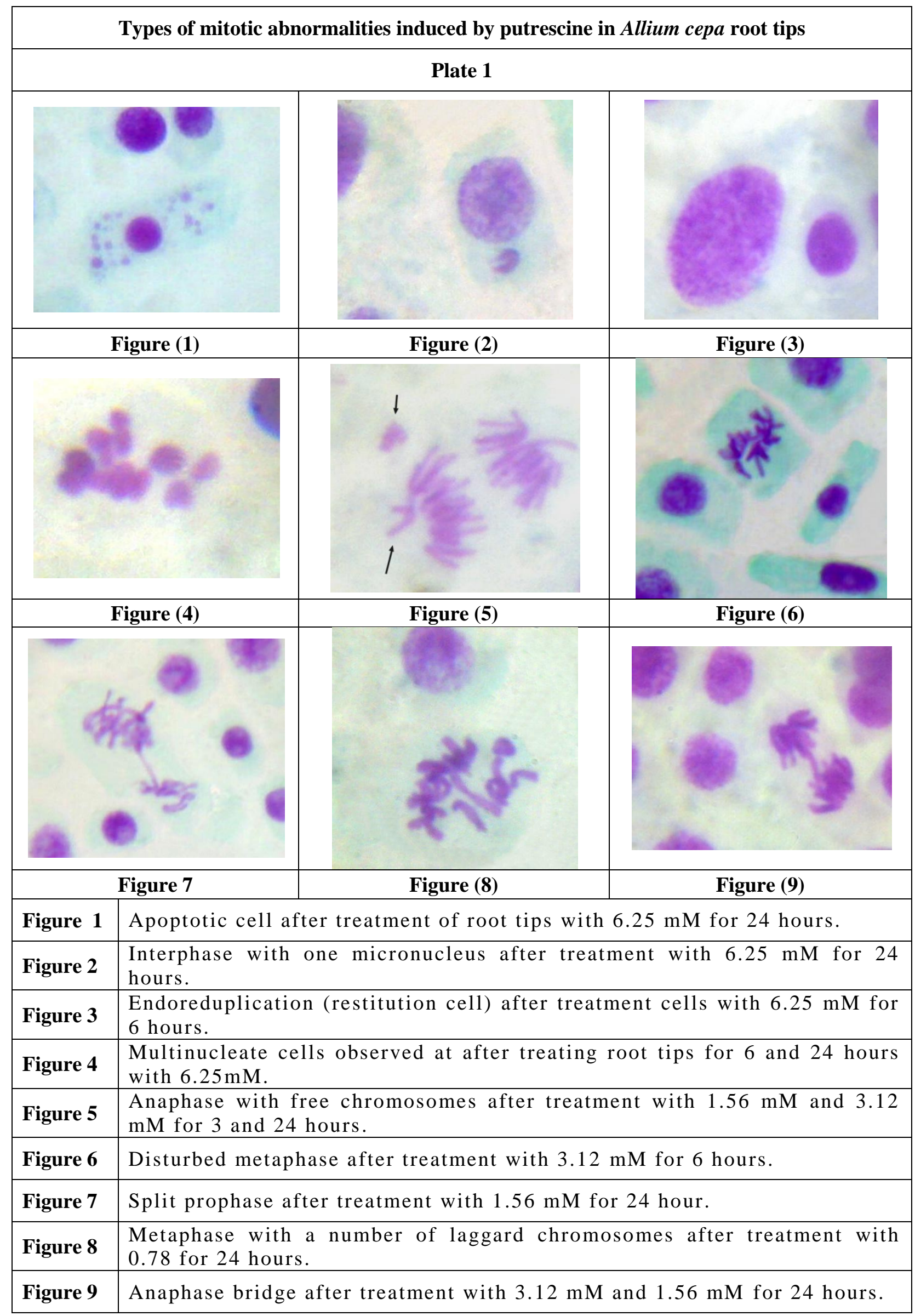


The association between the inhibitory effects of putrescine with its action on cell cycle parameters it can be concluded that, the reduction in mitotic activity may be regarded as a result of arrest of mitotic cycle at $G_{2}$ phase andlor the prolonged duration of S-phase but not to inhibiting DNA synthesis.

The malfunctioning of cell cycle phases can be detected by deviation from normal cell progression through presence of aneuploidy (corresponding to changes in chromosome copy number and DNA breaks) and polyploidy (multiplication of normal DNA content). It is widely accepted that chromosomal abnormalities occur predominantly in aneuploid malignant cells, leading to progressive deterioration of cancer ${ }^{33}$. Similarly the pretreated Allium cepa root tips will show chromosomal abnormalities that are expected to be similar to aneuploid and polyploidy cases in cancer examined cells, corresponding to treated dose and period of treatment. Also polyploidy shows several disadvantages, firstly the nuclear and cell enlargement ${ }^{34}$; this increase imposes changes in cellular architecture, in relation to other regulatory implications. Secondly, reduction of mitosis through which cells undergoes successive DNA replications without any subsequent mitosis and cytokinesis. In what is known as endoreduplication is frequently observed in some, but not all, plants as the level of ploidy varies between different species and in different tissues in same plant ${ }^{35}$.

From the results of image cytometric analysis it is clear that there is obvious correlation between the higher ploidy percentage and chromosomal abnormalities, one of the causes for decrease in mitotic indices observed in cytogenetic analysis for different exogenous treatments of hormones.

\section{References}

1) Davies P. J. (2004): Plant Hormones: Biosynthesis, Signal Transduction, and Action, 3rd Ed. Published by Kluwer Academic Publishers.

2) Heby, O., \& Persson, L. (1990) : Molecular genetics of polyamine synthesisin eukaryotic cells. Trends Biochem. Sci., 15, 153-158.

3) Pegg A.E. and McCann P.P. (1982): Polyamine metabolism and function .Am J Physiol., Nov; 243(5):C212-21.

4) Marton L.J. and Pegg A.E. (1995): Polyamines as targets for therapeutic intervention. Ann Rev Pharmacol Toxicol.35, 55-91.

5) Wallace, H. M., Fraser, A. V., \& Hughes, A. (2003): A perspective of polyamine metabolism. Biochem. J., 376, 1-14.

6) Darlington, C. D. and La- Cour, L. F. (1976). The handling of chromosomes, sixth ed. George Allene and Unwin., LTD. London.

7) BŜcking A., Giroud F., Reith A. (1995): Consensus report of the ESACP task force on standardization of diagnostic DNA image cytometry. Anal Cell Pathol, 8, 67-74.

8) Danque, P.D.; Chen, H.B.; Patil, J.; Jagirdar, J.; Orsatti, G. and Paronetto, F. (1993): Image analysis versus flow cytometry for DNA ploidy quantitation of solid tumors; A comparison of six methods of sample preparation. Mod. Pathol. 6; 270-275.

9) Lee, S.; Tolmachoff, Y. and Marchevsky, A.M. (1994): DNA content analysis (ploidy) by image analysis. Clinical applications and comparison with flow cytometry. In image analysis; a prime for pathologists. Edited by Marchevsky, A.M. and Bartels, P.H., Raven Press. Ltd. New York, PP. 261288.

10) Huang Q., Yu CH., Zhang X. and Goyal R.K.(2008) : Comparison of DNA histograms by standard flow cytometry and image cytometry on sections in Barrett's adenocarcinoma.BMC Clinical Pathology 2008, 8:5.

11) Mohands, $T$ and W.F. Grant (1972) :cytogenetic effects of 2,4-D and amitrol in relation to nuclear volume and DNA content in some higher plants. Can.j.Genet.cytol, 14:773-778.

12) Kim,J. and E.L. bendixen (1987). Effect of haloxyfop and CGA-82725 on cell cycle and cell division of oat (Avena sativa) root tips. Weed sci., 35:769-774

13) Glab,N.B. labidi; L. Qin; Ch. Trehin; C. Bergounioux and L. meijer(1994). Olomoucine, an inhibitor of the cdc $2 / \mathrm{cdk} 2$ kinases activity, blocks plant cells at the $G_{1}$ to $S$ and $G_{2}$ to $M$ cell cycle transitions. FEBS Lett. 353:207-211.

14) Mohanty S.;A.B.Das; P.Das and P. Mohanty(2004) : Effect of a low dose of aluminium on mitotic and meiotic activity, 4C DNA content, and pollen sterility in rice, Oryza sativa L.Ecotoxicol Mol. Mutagen., 41:353-359.

15) Keul, L.G. and M. Keul (1994): The effect of carbendazin on cell cycle in the root meristems of Triticium aestivum Sp vulgare and Vicia faba Fev.Roum.biol. ser bio Veg., 28:131-136.

16) Polit J.T.; J. Maszewski and A. Kazmierczak (2003) :Effect of BAP and IAA on the expression of G1 and G2 control points and G1-S and G2-M transitions in root meristem cells of Vicia faba. CellBiol.Int, 27:559-566.

17) Rencüzogülları E., B. 'Ila H., Kayraldız A., Topaktas M. (2001): Chromosome aberrations and sister chromatid exchanges in cultured human lymphocytes treated with sodium metabisulfite a food preservative, Mutat. Res. /Genet. Toxicol. Environ. Mutagen. 490:107-112.

18) Jayabalan N. and Rao G.R(1987) : Gamma radiation induced cytological abnormalities in Lycopersicon esculentum Mill. Var. Pusa Ruby.Cytologia 52: 1-4.

19) Gaulden, M.E. (1987) :Hypothesis: Some mutagens directly alter specific chromosomal proteins (DNA topoisomerase II and peripheral proteins) to produce chromosome stickiness, which causes chromosome aberrations. Mutagenesis 2: 357-365.

20) Gömürgen A.N. (2005): Cytological effect of the potassium metabisulphite and potassium nitrate food preservative on root tips of Allium cepa L., Cytologia 70:119-128. 
21) Kovalchuk O., Kovalchuk I., Arkhıpov A. Telyuk P., Hohn B. and Kovalchuk L., (1998): The Allium cepa chromosome aberration test reliably measures genotoxicity of soils of inhabited areas in the Ukraine contaminated by the chernobyl accident. Mutation Research, 415: 47-57.

22) Fisun K. and Goc Rasgele P. (2009): Genotoxic effects of raxil on root tips and anthers of Allium cepa 1. Caryologia Vol. 62, no. 1: 1-9.

23) El-Ghamery, A.A., El-Nahas, A.I., Mansour, M.M. (2000) :The action of atrazine herbicide as an inhibitor of cell division on chromosomes and nucleic acids content in root meristems of Allium cepa and Vicia faba, Cytologia 65:277-287.

24) Renata-Kontek; Osiecka R. and Bodgan K. (2007): Clastogenic and mitodepressive effects of the insecticide dichlorvos on root meristems of Vicia faba. J. Appl. Genet. 48(4): 359-361.

25) Singh, P. (2007): Comparative sensitivity of barely (Hordeum vulgare L.) to insecticide and fungicide on different stages of cell cycle. Pesticide Biochemistry and physiology 89 (3): 216-219.

26) Aydemir N., Çelikler S., Summak S., Yılmaz D., Özer Ö. (2008): Evaluation of Clastogenicity of 4, 6-Dinitro-o-cresol (DNOC) in Allium Root Tip Test. J. BIOL. ENVIRON. SCI., 2(5): 59-63.

27) Fenech M., Crott J., Turner J., Brown S. (1999): Necrosis, apoptosis, cytostasis and DNA damage in human lymphocytes measured simultaneously within the cytokinesis block micronucleus assay: description of the method and results for hydrogen peroxide. Mutagenesis 14 (November (6)):605-612.

28) Fenech, M. (2007): Cytokinesis-block micronucleus cytome assay, Nat. Protoc. 2 (5):1084-1104.

29) Martins, L. M. and Earnshaw, W. C. (1997): Apoptosis: Alive and kicking, Trends Cell Biol., 7:111-114.

30) Green, D. R. (1998) :Apoptotic pathways: The roads to ruin. Cell, 94: 695-698.

31) Ellis, R. R., Yuan, J. and Horvitz, H. R.: (1991) Mechanisms and functions of cell death. Annu. Rev. Cell Biol., 7:663-698.

32) Harting, K. and Beck (2006).Crosstalk between auxins, cytokinins and sugar in the plant cell cycle. Plant Biol., 8:1-8.

33) Ghadimi R.M., Sackett D.I., Difilippantonio M.J., Schrock E., Neumann T.,Jauho A., Auer G., Ried T.(2000): Centrosome amplification and instability occurs exclusively in aneuploid, but not in diploid colorectal cancer cell lines, and correlates with numerical chromosomal aberrations. Genes Chromosomes Cancer, 27:183-190.

34) Melaragno, J. E., Mehrotra, B. \& Coleman, A. W (1993): Relationship between endopolyploidy and cell size in epidermal tissue of Arabidopsis. Plant Cell , 5:1661-1668.

35) Sugimoto-Shirasu K, Roberts K (2003): 'Big it up': endoreduplication and cell-size control in plants. Curr Opin Plant Biol, 6: 1-10. 